\title{
Changes in the Biochemical and Mineral Composition of Hilsa Shad, Tenualosa ilisha (Hamilton, 1822) during Upstream Spawning Migration
}

\author{
Munish Kumar ${ }^{1}$, Tincy Varghese ${ }^{1}$, Narottam Prasad Sahu ${ }^{1}$, \\ Gyandeep Gupta ${ }^{1}$ and Subrata Dasgupta ${ }^{2 *}$
}

\author{
${ }^{1}$ Fish Nutrition Biochemistry \& Physiology Division, ICAR-Central Institute of Fisheries \\ Education, Versova - 400 061, Mumbai, India \\ ${ }^{2}$ ICAR-Central Institute of Fisheries Education, Kolkata - 700 09, India
}

*Corresponding author

\section{A B S T R A C T}

A study was conducted to examine the changes in biochemical composition consisting moisture, protein, lipid, carbohydrate, ash content and mineral composition of Indian shad,

Keywords

Hilsa, Biochemical composition, Ionic composition, Upstream migration,

Seawater,

Freshwater

Article Info

Accepted:

04 May 2019

Available Online:

10 June 2019 hilsa (T. ilisha) during upstream migration for spawning from off-shore of the Bay of Bengal to the Bhagirathi-Hooghly zones of the Ganga river system in India. Adult hilsa fish were collected from seawater (SW), freshwater 1 (FW1) and freshwater 2 (FW2) locations, where the salinity level was $26-28 \%, 1-5 \%$ and $0-0.04 \%$ respectively. The moisture and carbohydrate varied significantly among three locations, but not the protein and ash contents. The moisture content of hilsa collected from different habitats ranged between $62.40 \%$ and $68.71 \%$, whereas, the protein, lipid, carbohydrate and ash percentages were $15.22 \%, 12.61 \%, 0.84 \%, 2.59 \%$ and $15.59 \%, 14.35 \%, 3.85 \%, 3.78 \%$ in seawater and freshwater respectively. The minerals like sodium, potassium and calcium were highest in SW hilsa compared to FW hilsa. However, iron content was highest in FW hilsa compared to SW hilsa. The results indicate that the migration influences the nutritive value of hilsa, as the lipid, sodium, potassium and calcium levels significantly reduced during upstream river migration. It further, point out that the lipid and carbohydrate mobilized as the energy source to support long migration and gonadal development. The ionic profile of hilsa muscle showed location effects, and the values declined while the fish migrated through freshwater indicates that the energy driven metabolic processes might govern the acclimation of upstream migration and spawning of T. ilisha.

\section{Introduction}

Indian shad, hilsa is recognized as one of the most delicious, commercial fish of the IndoPacific region, which belongs to the subfamily Alosinae of Family Clupeidae. The hilsa shad is a long distance anadromous fish which migrates from its marine environment to the freshwater rivers for spawning. From offshore water of the Bay of Bengal, the fish ascend into the Ganga River twice a year, during February to March, and September to October (Ahasan et al., 2014). It has a broad range of geographical distribution and found 
along marine, estuarine and riverine waters of Persian Gulf, Red Sea, Arabian Sea, Bay of Bengal, Vietnam Sea and China Sea. Indian rivers, namely the Hooghly Bhagirathi stretch of the Ganga, Godavari, Narmada, Tapti and other coastal rivers bestowed with hilsa fishery. The significant portion of hilsa (about $90 \%$ ) caught by Bangladesh, India and Myanmar (Bhaumik, 2013). The hilsa is a highly prised food fish accounting $15-20 \%$ of the total fish landings of the Hooghly estuary (Mohanty et al., 2011). The nutritional importance of fish consumption to a great extent associated with its protein, unsaturated essential fatty acids, minerals and vitamins (Sidhu, 2003).

Fish and seafood play a significant role in human nutrition and health, which provide the balance of proteins, lipids, vitamins, minerals and have a relatively low caloric value than other muscle foods. The flesh of hilsa is an excellent source of proteins in the human diet and preferred by most of the fish eaters due to its pleasant taste and smell. The biochemical composition is a good indicator of the physiological condition of fish (Ali et al., 2005).

The nutritional composition of fish varies greatly from species to species and within the species, depending on age, feed intake, physical activity, sex and sexual changes connected with spawning, environment or geographical localities and season. Energy resources partition between an animal's metabolic activity, growth performance and reproduction. The nutritional status and consequently muscle composition is directly affected by the reproductive activity. Principal constitutes of fish is $16-21 \%$ protein, $0.2-25 \%$ fat, $1.2-1.5 \%$ carbohydrate and 66-81\% water (Love, 1970). The biochemical composition varies greatly from species to species and also from individual to individual depending on age, sex, environment and season (Huss, 1988). During somatic growth, the protein, lipid, and ash typically accumulate while protein and lipid deplete during gonadal growth (Tanasschuk, 1989). Mostly anadromous fish accumulate a large amount of energy reserves prior to begin migration for spawning.

Although there is wealth of information on the biochemical composition of hilsa shad from different habitats (Rao et al., 2012; Begaum et al., 2016; Ganguly et al., 2017), changes in proximate and mineral composition in hilsa during upriver spawning migration from off-shore Bay of Bengal into Hooghly-Bhagirathi stretches of the Ganga river is limited. The present study was taken up with an objective to analyse the changes in the biochemical and mineral composition of hilsa shad during its anadromous migration from the Bay of Bengal to the BhagirathiHooghly stretches of the Ganga River.

\section{Materials and Methods}

\section{Sample collection, preservation and preparation}

The experimental animals of the study were hilsa adults (Tenualosa ilisha) with an average weight ranging from $225 \mathrm{gm}$ to $470 \mathrm{gm}$. The 15 fish samples were collected from the Digha (SW; 26 to 28\%o), Nischintopur (FW1; 1 to $5 \%$ ) and Shyamnagar (FW2; 0 to $0.04 \%$ ) along Bhagirathi-Hooghly stretch of the Ganga river system in the West Bengal. The collected live fish samples were washed properly with deionised water to remove all dirt's, slime, and length and weight of the fish were recorded.

The fish were cut into fillets, packed in plastic bags and transported in dry ice to the Central Institute of Fisheries Education, Kolkata centre, West Bengal. Fifteen fish used for taking samples for all biochemical analysis. 


\section{Physicochemical parameters of water}

The physico-chemical parameters such as, temperature, salinity, alkalinity, total suspended solids (TSS) and total dissolved solids (TDS) estimated using standard methods (APHA, 2017).

\section{Proximate analysis}

For proximate analysis, all the dissected fishes from different salinities weighed and kept in pre weighed Petri plates. Moisture, protein, lipid, carbohydrate and ash were determined as per standard methods (AOAC, 2006). Moisture (\%) was calculated after drying the different sampled fish were dried in hot air oven at $100^{\circ} \mathrm{C} \pm 2$ till a constant weight. After complete drying, the fish of different salinities were ground into the fine powder with a pestle and mortar. Crude protein content $(\mathrm{N} \% \times 6.25)$ was estimated after acid digestion using semi-automatic nitrogen analyzer (2200 Kjeltec auto distillation; Foss Tecator, Hoganas Sweden). Crude lipid was determined by the etherextraction method in a soxhlet extraction apparatus (Socsplus, SCS-08-AS, Pelican equipment, Chennai, India), ash content was determined after burning the dried samples in muffle furnace at $550^{\circ} \mathrm{C}$ for $6 \mathrm{~h}$ and carbohydrate was determined by subtracting the water, protein, fat and ash from 100 .

\section{Osmolality and minerals}

Water osmolality of FW and SW samples were measured using a vapour pressure osmometer (Model 5600). Concentration of ions such as sodium $\left(\mathrm{Na}^{+}\right)$, potassium $\left(\mathrm{K}^{+}\right)$, chloride $\left(\mathrm{Cl}^{-}\right)$, calcium $\left(\mathrm{Ca}^{++}\right)$ions of water as well as muscle were measured using Eschweiler Combi Blood Electrolyte Analyzer (Diamond Diagnostics-USA). The iron content from digested muscle samples were analyzed by atomic absorption spectrophotometer (A Analyst 800, Perkin Elmer) according to the manufacturer's instructions.

\section{Statistical analysis}

Data collected were subjected to one way analysis of variance (ANOVA) and statistical comparisons between treatments were made by the Tukey honest significant difference (HSD) test using SPSS version 12.0 software for Windows. The significance of observed differences was tested at $\mathrm{p}<0.05$.

\section{Results and Discussion}

Upstream migrations in lotic systems are energetically demanding, and mostly feeding during long-distance migrations is scarce. As a result, anadromous species rely heavily on energy reserves that they accumulate in the months preceding migration. The degree of utilizing energy reserves is highly variable both among species and populations. The iteroparous species deplete only 35 to $60 \%$ of their stored energy compared to 75 to $82 \%$ in semelparous species like salmon, shads. Also, migration associated with gonad development and spawning demands much more power. Hilsa being an anadromous and iteroparous fish must face such depletion during spawning migration run and which positively influences central energy reserves, such as, proteins, carbohydrates, and lipids. Moreover, mineral contents may also vary owing to change in the ionic environment during migration. As consequences, nutritional values of hilsa may be increased as reported in the hilsa from Godavari River (Rao et al., 2012) and earns many consumers preference.

It is essential to understand how environmental parameters vary at different locations across the migratory path, which ultimately dictates physiological strategies of fish for acclimating in various saline habitats. 
The sampling locations i.e., SW, FW1 and FW2 exhibited remarkable variations in physiochemical parameters such as temperature, salinity, alkalinity, TSS, TDS, $\mathrm{Na}^{+}, \mathrm{K}^{+}, \mathrm{Cl}^{-}$and $\mathrm{Ca}^{++}$ions concentrations and osmolality (Table 1). As expected, the ion concentrations were highest in the SW compared to the FW1 and FW2. When hilsa migrate from SW to $\mathrm{FW}$ environment and vice versa as other anadromous species, they need to adjust ionic and osmotic balance in their internal milieus differently to the salinities of external environment for their survival in hypertonic SW or hypotonic FW.

In the present study, the biochemical composition of $T$. ilisha collected from (SW) and FW1 and FW2 in the Ganga river system; the FW2 was away from saltwater intrusion. The changes in the biochemical composition of whole fish consisting moisture, crude protein, total lipid, total carbohydrates, and ash during anadromous migration from marine to the riverine environment are presented in Figure 1.

The moisture content of hilsa fluctuated from $62.40 \%$ to $68.71 \%$; the lowest moisture content was recorded in SW (62.40\%), the value increased in the fish migrated to the upstream river at FW1 (64.56\%) and FW2, $(68.71 \%)$. The moisture content was within the range (58.82 to $69.54 \%$ ) as reported by Majumda and Basu (2009) in hilsa from Bangladesh and $66.90 \%$ from FW environment (Mohanty et al., 2017). The moisture content of fish muscle has an inverse relationship with lipids and proteins (Lone and Matty, 1980). Protein is an indispensable nutrient required for the structure and function of all living organisms. The protein content of the muscle varies widely depending on factors such as feeding habits and availability of food, fasting, and migration, etc. (Sahikhmahmud and Magar, 1957). Muscle protein depleted during periods of fasting or starvation. The variation in the protein content of hilsa during anadromous migration was not very conspicuous. In the present study, there was no significant difference in protein content, although it was numerically higher in the SW hilsa $(15.59 \%)$ as compared to FW1 (15.24\%) and FW2 $(15.22 \%)$. In the present study, the muscle protein levels in different saline environments were less than those reported earlier, the range of 16.80 to $20.7 \%$ (Kamal et al., 1996; Majumdar and Basu, 2009; Majumdar and Basu, 2010; Hossain et al., 2014; Mohanty et al., 2017). The highest ash content was observed in SW (3.78\%) compared to those at FW1 (3.06\%) and FW2 (2.59\%) respectively. However, the muscle ash content reported in the study was slightly higher than those reported earlier as $1.1 \%$ (Mohanty et al., 2017) and 2.27\% (Saha and Guha, 1939). Total carbohydrate content was in the range of 0.84 to $3.85 \%$, and the highest value in SW hilsa declined when the fish migrated into FW locations.

The fat contents showed a significant difference $(\mathrm{p}<0.05)$ in $\mathrm{SW}, \mathrm{FW} 1$ and FW2 hilsa during its anadromous migration. The highest fat content in the SW (14.35\%) depleted while the hilsa migrated into FW1 (13.53\%) and in FW2 (12.61\%). The values were higher than the earlier report $(11.85 \%)$ of hilsa from the Sudarban estuary of West Bengal, India (Pal et al., 2011), whereas the present values were lower than those reported as $17.56 \%$ in hilsa from the Bay of Bengal (Kamal et al., 1996). Nath and Banerjee (2012), Rao et al., (2012) and Majumdar and Basu (2009) reported muscle lipid contents of $17.30 \%, 20.85 \%$ and $20.78 \%$ in hilsa from brackish water habitat in West Bengal, downstream of Hoogly River and Bangladesh, respectively. The pattern of lipid composition fluctuates and governs by the rate of fat metabolism, maturity stage, environmental temperature, food availability, stress and other 
factors (Sikorski et al., 1990). The higher lipid content found in hilsa from the Bay of Bengal could be related to their foods and active feeding behaviour. The biochemical composition of fish is strongly affected by food contents (Henderson and Tocher, 1987; Orban et al., 2007). Hilsa feeds on plankton, mainly by filtering, but also by grubbing on the muddy bottom. The fat content decrease in spawning period is due to mobilization of fat related to gametogenesis (Sharer, 1994).

Our results suggest that fish accumulate fat in the marine environment before the initiation of spawning and then proceed upwards into the Bhagirathi-Hooghly stretch of the Ganga river system. Hilsa accumulate energy reserves during their growth phase in the form of lipids, mainly as triglycerides which are catabolized to provide the energy which is necessary for anadromous migration and gametogenesis. Jonsson et al., (1997) reported a decrease in lipid content during the upward migration of Atlantic salmon. Body lipid decreased by 30 to $40 \%$ during the period of re-entry of Arctic charr to FW from SW, and the female fish lost $80 \%$ of their body lipids during spawning (Josrgensen et al., 1997). The migration of European eels is heavily dependent on the fats stored during their growth phase (Boetius and Boetius, 1985).

Minerals are essential for growth, bone mineralization, reproduction, and energy metabolism in all living organisms. The significant portion of minerals in the fish body concentrated in muscle, scale, and vertebrae (Lall, 2002). The prominence of each mineral element in body tissue is closely related to its functional role. The macrominerals which include calcium, phosphorous, magnesium, sodium, chloride and potassium occur in the body at a concentration ranging from 0.1 to $2.0 \%$ of fish mass (Lall, 1995). Earlier evidence support that the hilsa flesh is a rich source of various essential minerals. The present study showed the $\mathrm{K}^{+}$was the most abundant elements in muscle followed by $\mathrm{Na}^{+}, \mathrm{Ca}^{++}$and Fe content (Table 2).

The muscle $\mathrm{K}^{+}$levels (601-1203 mg/100g) were slightly lower than those of 1390 $\mathrm{mg} / 100 \mathrm{~g}$ reported for Pseudotolithus elongates muscle (Njinkoue et al., 2016); however, it was similar to $613 \mathrm{mg} / 100 \mathrm{~g}$ and $573 \mathrm{mg} / 100 \mathrm{~g}$ in hilsa muscle collected from the Bay of Bengal (Hossain et al., 2014;Rao et al., 2012). $\mathrm{Ca}^{++}$is the essential nutrients for growth and significant constituent of the structural components of skeletal tissues. The $\mathrm{Ca}^{++}$level in the muscle ranged from 120 to168 $\mathrm{mg} / 100 \mathrm{~g}$ ) and was similar (155-204 $\mathrm{mg} / 100 \mathrm{~g}$ ) to the hilsa of Bay of Bengal (Hossain et al., 2014).

The muscle $\mathrm{Na}^{+}$content ranged between 82.26 and $199.6 \mathrm{mg} / 100 \mathrm{~g}$ in $\mathrm{SW}$ and $\mathrm{FW}$ environments, which is similar to the marine hilsa $(183 \mathrm{mg} / 100 \mathrm{~g})$ from the Bay of Bengal and Godavari hilsa (83 mg/100g) as reported by Rao et al., (2012). Iron plays a critical role within cells assisting in haemoglobin synthesis, oxygen utilisation, enzymatic systems, especially for neural development and overall cell function all over the body. The iron (Fe) level in the muscle varied between 1.46 and $2.67 \mathrm{mg} / 100 \mathrm{~g}$ during migration, the level in $\mathrm{FW}$ was higher compared to the hilsa intercepted from SW locations. The present level of muscle iron was similar to the average iron value reported in different sizes of hilsa of the Ganga River (Ganguly et al., 2017) and Bay of Bengal, however it was less than the value reported from the Arabian Gulf (Hossian et al., 2014). The concentration of minerals and trace element levels are known to vary in fish depending on various factors such as their feeding behaviour, environment, ecosystem and migration (Andres et al., 2000). 
Table.1 Water quality parameters of different habitats

\begin{tabular}{|l|c|c|c|}
\hline Parameters & SW & FW1 & FW2 \\
\hline Temperature $\left({ }^{\mathbf{0}} \mathbf{C}\right)$ & $25.5-25.50$ & $23-23.50$ & $22-23.00$ \\
\hline Ph & 8.15 & 7.75 & 7.65 \\
\hline Salinity (\%) & $26.00-28.00$ & $1.00-5.00$ & $0.00-0.04$ \\
\hline $\begin{array}{l}\text { Osmolality } \\
(\mathbf{m m o l} / \mathbf{k g})\end{array}$ & $810.50^{\mathrm{a}} \pm 4.50$ & $76.00^{\mathrm{b}} \pm 1.00$ & $0.00^{\mathrm{c}} \pm 0.00$ \\
\hline $\mathbf{T S S}(\mathbf{m g} / \mathbf{L})$ & $163.15^{\mathrm{b}} \pm 6.29$ & $406.16^{\mathrm{a}} \pm 9.45$ & $74.13^{\mathrm{c}} \pm 5.15$ \\
\hline $\mathbf{T D S}(\mathbf{m g} / \mathbf{L})$ & $34198.68^{\mathrm{a}} \pm 534.08$ & $3692.88^{\mathrm{b}} \pm 145.97$ & $59.16^{\mathrm{c}} \pm 5.05$ \\
\hline Alkalinity $(\mathbf{m g} / \mathbf{L})$ & $134.33^{\mathrm{a}} \pm 3.28$ & $142.0^{\mathrm{a}} \pm 4.04$ & $104.33^{\mathrm{b}} \pm 2.18$ \\
\hline $\mathbf{C a}^{++}(\mathbf{m g} / \mathbf{1 0 0 m L})$ & $27.91^{\mathrm{a}} \pm 1.14$ & $5.75^{\mathrm{b}} \pm 0.89$ & $3.48^{\mathrm{c}} \pm 0.53$ \\
\hline $\mathbf{K}^{+}(\mathbf{m g} / \mathbf{1 0 0} \mathbf{m})$ & $33.21^{\mathrm{a}} \pm 0.13$ & $3.94^{\mathrm{b}} \pm 0.23$ & $0.76^{\mathrm{c}} \pm 0.05$ \\
\hline $\mathbf{N a}^{+}(\mathbf{m g} / \mathbf{1 0 0 M L})$ & $846.81^{\mathrm{a}} \pm 14.18$ & $110.30^{\mathrm{b}} \pm 3.20$ & $17.23^{\mathrm{c}} \pm 1.77$ \\
\hline $\mathbf{C l}^{-}(\mathbf{m g} / \mathbf{1 0 0 M L})$ & $1169.85^{\mathrm{a}} \pm 25.18$ & $191.43^{\mathrm{b}} \pm 5.02$ & $40.76^{\mathrm{c}} \pm 3.16$ \\
\hline
\end{tabular}

Water physico-chemical parameters at different locations SW, FW1 and FW2.Mean values bearing different superscripts under each row varied significant $(\mathrm{p}<0.05)$. Data expressed as Mean $\pm \mathrm{SE},(\mathrm{n}=6)$

Table.2 Mineral composition of hilsa muscle from different habitats (dry weight basis; mg/100

g)

\begin{tabular}{|c|c|c|c|c|}
\hline $\begin{array}{c}\text { Muscle } \\
\text { sample }\end{array}$ & Iron & Calcium & Sodium & Potassium \\
\hline SW & $1.46^{\mathrm{c}} \pm 0.11$ & $1680^{\mathrm{a}} \pm 9.86$ & $199.60^{\mathrm{a}} \pm 8.79$ & $1203.86^{\mathrm{a}} \pm 12.04$ \\
\hline FW1 & $2.28^{\mathrm{b}} \pm 0.04$ & $140.33^{\mathrm{b}} \pm 2.90$ & $106.20^{\mathrm{b}} \pm 7.37$ & $714.60^{\mathrm{b}} \pm 7.96$ \\
\hline FW2 & $2.67^{\mathrm{a}} \pm 0.10$ & $120.00^{\mathrm{c}} \pm 4.35$ & $82.26^{\mathrm{c}} \pm 3.3$ & $601.00^{\mathrm{c}} \pm 10.57$ \\
\hline
\end{tabular}

Values are expressed as Mean \pm SE, $(n=6)$. Values in the same column with different superscript letters are significantly different ( $\mathrm{P}<0.05)$. SW (26 to 28\%), FW1 (1 to 5\% ) and FW2 (0 to 0.04\%)

Fig.1 Changes in biochemical composition of whole body of Tenualosa ilisha adults during upstream migration. Values are expressed as Mean $\pm \mathrm{SE},(\mathrm{n}=15)$. The bar bearing different superscript differ significantly ( $\mathrm{p}<0.05)$. SW (26 to $28 \%$ ), BW (1 to $5 \%$ ) and FW (0 to $0.04 \%$ )

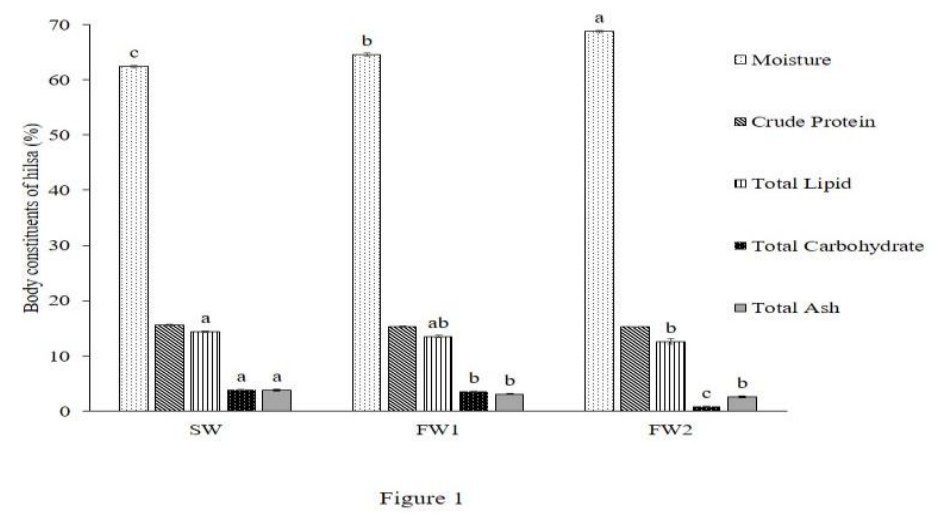


In conclusion, supply of energy is essential for osmoregulatory acclimation in the changing environment and spawning during migration in fish. As the lipid is the principal substrate of energy, the depletion and mobilization of fat was more prominent and might be linked with both osmoregulation and spawning in the fish. The present study reveals that lipid and ionic levels of muscles depleted in hilsa while migrated from the offshore Bay of Bengal into freshwater stretches of the river Ganga supporting the enzymemediated metabolic processes might govern the acclimation of upstream migration and spawning of T. ilisha.

\section{Acknowledgements}

The authors are grateful to the Director, Central Institute of Fisheries Education, Mumbai, for providing facilities for carrying out the research work. The first author is grateful to the CIFE for the institutional fellowship provided during the period of work.

\section{References}

Ahasan, D.A., Naser, M.N., Bhaumik, U., Hazra, S., and Bhattacharya, S.B. 2014. Migration, spawning patterns and conservation of hilsa shad (Tenualosa ilisha) in Bangladesh and India. Academic Foundation, New Delhi, pp. 1-95.

Bhaumik, U. 2013. Decadal studies on Hilsa and its fishery in India-A Review. J. Interacademicia, 17: 377-405.

Mohanty, B.P., Das, S., Bhaumik, U., and Sharma, A.P. 2011. Tenualosa ilishaA Rich Source of Omega-3 Fatty Acids (CIFRI Bulletin no. 171).

Sidhu, K.S., 2003. Health benefits and potential risks related to consumption of fish or fish oil. Regul. Toxicol. Pharmacol. 38: 336-344.
Ali, M., Iqbal, F., Salam, A., Iram, S., and Athar, M. 2005. Comparative study of body composition of different fish species from brackish water pond. Int. J. Environ. Sci. Technol. 1: 229-32.

Love, R.M. 1970. The chemical biology of fishes. With a key to the chemical literature.

Huss, H.H. 1988. Fresh fish quality and quality changes: a training manual prepared for the FAO/DANIDA Training Programme on Fish Technology and Quality Control (No. 29). Food \& Agriculture Org.

Tanasschuk, R.W., and Mackay, W.C. 1989. Quantitative and qualitative characteristics of somatic and gonadal growth of yellow perch (Perca flavescens) from Lac Ste. Anne, Alberta. Can. J. Fish. Aquat. Sci. 46: 989-994.

Rao, B.M., Murthy, L.N., Mathew, S., Asha, K.K., Sankar, T.V., and Prasad, M.M. 2012. Changes in the nutritional profile of Godavari hilsa shad, Tenualosa ilisha (Hamilton, 1822) during its anadromous migration from Bay of Bengal to the River Godavari.

Begum, M., Bhowmik, S., Juliana, F.M., and Hossain, M.S. 2016. Nutritional Profile of Hilsa Fish Tenualosa ilisha (Hamilton, 1822)] in Six Selected Regions of Bangladesh. IJNFS6: 2.

Ganguly, S., Mahanty, A., Mitra, T., Mohanty, S., Das, B.K., and Mohanty, B.P. 2017. Nutrigenomic studies on hilsa to evaluate flesh quality attributes and genes associated with fatty acid metabolism from the rivers Hooghly and Padma. Food Res. Int. 103: 21-29.

AOAC.2006. Official Methods of Analysis. 18th Edition, Association of Official Analytical Chemists, Gaithersburgs, MD.

Majumdar, R.K., and Basu, S. 2009. Studies 
on seasonal variation in the biochemical composition of the Indian shad, Tenualosa ilisha (Hamilton, 1822). Indian J. Fish.56: 205-209.

APHA., 2017. Standard Methods for the Examination of Water and Waster water, 23rd Edition, American Public Health Association, American Water Works Association, Water Environment Federation.

Mohanty, B.P., Mahanty, A., Ganguly, S., Mitra, T., Karunakaran, D., and Anandan, R. 2017. Nutritional composition of food fishes and their importance in providing food and nutritional security. Food Chem. 555.

Lone, K.P., Matty, and A.J. 1980. The effect of feeding methyltestosterone on the growth and body composition of common carp (Cyprinus carpio). Gen. Comp. Endocrinol.40: 409-424.

Sahikhmahmud, F.S., and Magar, N.G. 1957. Studies in nutritive value of Bombay prawns. Part I. Chemical composition of prawns. JSIR 16:44-46.

Kamal, M., Islam, M.N., Mansur, M.A., Hossain, M.A., and Bhuiyan, M.A.I. 1996. Biochemical and sensory evaluation of hilsa fish (Hilsa ilisha) during frozen storage.

Majumdar, R.K., and Basu, S. 2010. Characterization of the traditional fermented fish product Lonailish of Northeast India.

Hossain, M.A., Almatar, S.M., and Al-Hazza, A.A. 2014. Proximate, fatty acid and mineral composition of hilsa, Tenualosa ilisha (Hamilton 1822) from the Bay of Bengal and Arabian Gulf. Indian J. Fish.61:58-66.

Saha, K.C., and Guha, B.C.1939. Nutritional investigations on Bengal fish. Indian J. Med. Sci. 26, 921-927.

Pal, M., Mukhopadhyay, T., and Ghosh, S. 2011. Proximate, Fatty Acid, and Amino Acid Compositions of Fish
Muscle and Egg Tissue of Hilsa (Tenualosa ilisha). J. Aquat. Food Prod. T.20: 160-171.

Nath, A.K., and Banerjee, B. 2012. Comparative evaluation of body composition of hilsa, Tenualosa ilisha (Hamilton, 1822) in different size groups with special reference to fatty acid, in Hooghly estuarine system, West Bengal, India. Indian J. Fish. 59: 141-146.

Sikorski, Z., Kolakowska, A., and Pan, B.S. 1990. The Nutritive Composition of the Major Groups of Marine Food Organisms (Chapter 3) Seafood: Resources.

Henderson, R.J., and Tocher, D.R. 1987. The lipid composition and biochemistry of freshwater fish. Prog. Lipid Res. 26, 281-347.

Orban, E., Nevigato, T., Masci, M., Dilena, G., Casini, I., Caproni, R., Gambelli, L., Deangelis, P., and Rampacci, M. 2007. Nutritional quality and safety of European perch (Perca fluviatilis) from three lakes of Central Italy. Food Chem. 100:482-490.

Sharer, K.D.1994. Factors affecting the proximate composition of cultured fishes with emphasis on salmonids. Aquaculture 119:63-88.

Jonsson, N., Jonsson, B., and Hansen, L.P.1997. Changes in the proximate composition and estimates of energetic costs during upstream migration and spawning in Atlantic salmon (Salmosalar). J. Anim. Ecol.66:425-436.

Josrgensen, E.H., Johansen, S.J.S., and Jobling, M.1997. Seasonal patterns of growth, lipid deposition and lipid depletion in anadromous Arctic charr. J. Fish Biol. 51: 312-326.

Boetius, I., and boetius, J. 1985. Lipid and protein content in anguillaanguilla during growth and starvation. Dana-a 
Journal of Fisheries and Marine Research 4:1-17.

Lall, S.P. 2002. Mineral nutrition. Fish nutrition, 3rd ed, Academic Press, San Diego, USA pp 260-308.

Lall, S.P. 1995. Macro and trace elements in fish and shellfish. In: Ruiter, A. (Ed.), Fish and fishery products: comparison, nutritive properties and stability. Wallingford: $\mathrm{CAB}$ International, pp. 187-214.

Njinkoue, J.M., Gouado, I., Tchoumbougnang, F., Ngueguim, J.Y., Ndinteh, D.T., Fomogne-Fodjo, C.Y., and Schweigert, F.J. 2016.
Proximate composition, mineral content and fatty acid profile of two marine fishes from Cameroonian coast: Pseudotolithus typus (Bleeker, 1863) and Pseudotolithus elongatus (Bowdich, 1825). IJNFS4: 27-31.

Andres, S., Ribeyre, F., Tourencq, J.N., and Boudou, A. 2000. Interspecific comparison of cadmium and zinc contamination in the organs of four fish species along a polymetallic pollution gradient (Lot River, France). Sci. Total Environ. 248:1125.

\section{How to cite this article:}

Munish Kumar, Tincy Varghese, Narottam Prasad Sahu, Gyandeep Gupta and Subrata Dasgupta. 2019. Changes in the Biochemical and Mineral Composition of Hilsa Shad, Tenualosa ilisha (Hamilton, 1822) during Upstream Spawning Migration. Int.J.Curr.Microbiol.App.Sci. 8(06): 338-346. doi: https://doi.org/10.20546/ijcmas.2019.806.038 